\title{
PENGARUH KEPEMIMPINAN TRANSFORMASIONAL DAN DISIPLIN KERJA TERHADAP KINERJA PERSONIL POLRI DENGAN KOMITMEN ORGANISASI SEBAGAI VARIABEL INTERVENING PADA POLRES KOTA LHOKSEUMAWE
}

\section{THE EFFECT OF TRANSFORMATIONAL LEADERSHIP AND WORD DICIPLINE ON POLICE PERFORMANCE WITH ORGANIZATIONAL COMMITMENT AS INTERVENING VARIABLE IN LHOKSEUMAWE POLICE RESORTS}

\author{
ISKANDAR \\ Program Pascasarjana Ilmu Manajemen, Fakultas Ekonomi dan Bisnis, Universitas Malikussaleh \\ (iskandar@gmail.com) \\ FAISAL MATRIADI \\ Program Pascasarjana Ilmu Manajemen, Fakultas Ekonomi dan Bisnis, Universitas Malikussaleh \\ (faisalmatriadi@unimal.ac.id) \\ AIYUB \\ Program Pascasarjana Ilmu Manajemen, Fakultas Ekonomi dan Bisnis, Universitas Malikussaleh \\ (aiyub@unimal.ac.id)
}

\begin{abstract}
ABSTRAK
Tujuan penelitian ini adalah mengetahui dan menganalisis pengaruh kepemimpinan transformasional dan disiplin kerja terhadap komitmen organisasi dan kinerja personil Polri di Polres Lhokseumawe. Banyaknya responden dalam penelitian ini yaitu 176 personil Polri yang bertugas di Polres Lhokseumawe. Metode analisis data yang digunakan adalah Structural Equation Modeling (SEM) dengan menggunakan softwere AMOS 21. Hasil penelitian ini menemukan bahwa secara langsung, kepemimpinan transformasional dan disiplin kerja berpengaruh signifikan terhadap komitmen organisasi, disiplin kerja dan komitmen organisasi berpengaruh signifikan terhadap kinerja personil, tetapi kepemimpinan transformasional tidak berpengaruh signifikan terhadap kinerja personil. Hasil pengujian efek mediasi menemukan bahwa komitmen organisasi memediasi secara parsial pengaruh disiplin kerja terhadap kinerja personil, tetapi tidak mampu memediasi pengaruh kepemimpinan transformasional terhadap kinerja personil
\end{abstract}

Kata Kunci: Kepemimpinan Transformasional, Disiplin Kerja, Komitmen Organisasi dan Kinerja Personil 


\section{ABSTRACT}

The purpose of this study was to determine and analyze the effect of transformational leadership and work discipline on organizational commitment and police performance of the Lhokseumawe Police Resorts. The number of respondents in this study were 176 police personnel who served in Lhokseumawe Regional Police. The data analysis method used is Structural Equation Modeling (SEM) using AMOS 21 software. The results of this study found that directly, transformational leadership and work discipline significantly influence organizational commitment, work discipline and organizational commitment significantly influence personnel performance, but leadership transformational does not have a significant effect on personnel performance. The mediation effect test results found that organizational commitment partially mediates the effect of work discipline on personnel performance, but is unable to mediate the effect of transformational leadership on personnel performance

Keywords: Transformational Leadership, Work Dicipline, Organizational Commitment and Police Performace

\section{PENDAHULUAN}

Sumber daya manusia merupakan salah satu unsur pelaksana kegiatan organisasi yang bertugas dan bertanggung jawab dalam kegiatan operasional organisasi. Dalam melaksanakan tugas, diperlukan suatu ketekunan dalam berkerja, cekatan dan memiliki keahlian serta kemampuan yang memadai (Khrishna et al., 2009). Kemajuan organisasi juga akan tercapai apabila sumber daya manusia memiliki kinerja yang baik (Mondiani, 2012; Manurung \& Riani, 2017). Akan tetapi, apabila kinerja sumber daya manusia tidak baik maka akan berimbas pada pencapaian tujuan organisasi (Manzoor et al., 2011). Oleh karena itu, kinerja menjadi aspek yang penting untuk diperhatikan demi mencapai tujuan organisasi.

Kinerja menjadi penting dikarenakan dengan tercapainya kinerja, maka output dari organisasi tersebut juga akan baik dan begitu sebaliknya (Zahabi, 2010). Keberhasilan organisasi sangat bergantung pada kinerja angota organisasi tersebut. Amirullah et al. (2017) mengatakan bahwa pengukuran kinerja pegawai hendaknya dapat diterjemahkan sebagai suatu kegiatan evaluasi kinerja terhadap keberhasilan dan kegagalan pencapain kinerja. Akan tetapi, evaluasi kinerja tidak semudah yang dibayangkan, karena setiap anggota organisasi memiliki kualitas kerja dan sifat yang berbedabeda (Anam, 2017). Hal tersebut membuat tugas manajer dan penyelia menjadi kompleks, sehingga penilaian kinerja sumber daya manusia merupakan isu yang masih menarik untuk dikaji.

Terdapat beberapa faktor yang mempengaruhi kinerja individu, seperti yang disampaikan oleh Kasmir (2016) yang menyebutkan bahwa kepemimpinan dan komitmen individu menjadi elemen yang dapat mempengaruhi kinerja. Selain itu, Kaswan (2012) berpendapat bahwa salah faktor yang mempengaruhi kinerja adalah disiplin kerja. Selain itu, riset-riset sebelumnya juga telah membuktikan bahwa variabel kepemimpinan transformasional, disiplin kerja dan komitmen organisasi berpengaruh signifikan terhadap kinerja (Mubarak \& Darmanto, 2016; Bangun, 2017; Nugraha et al., 2017; Rukhyati, 2018; Muis et al., 2018; Wibisono, 2018; Adil et al., 2018). Tetapi, temuan beberapa riset lainnya mendokumentasikan hasil yang kontradiktif, dimana variabel kepemimpinan transformasional, disiplin kerja dan komitmen organisasi tidak berpengaruh signifikan terhadap kinerja (Nurdin \& Rohendi. 2016; Kumarawati et al., 2017; Sefriady \& Iskanda, 2018; Siswatiningsih, 2018). Hal tersebut menunjukkan bahwa masih terjadi inkonsistensi hasil penelitian dari waktu ke waktu, sehingga penulis tertarik untuk mengkaji kembali. 
Uraian permasalahan teoritis di atas menunjukkan bahwa kepemimpinan transformasional, disiplin kerja dan komitmen organisasi berpengaruh terhadap kinerja, dimana konsep tersebut akan diterapkan dan di analisis pada para Personil Polri yang bertugas di Polres Lhokseumawe. Polri sendiri merupaka institusi pemerintah yang bertugas dan bertanggung jawab akan keteraturan sosial, Kamtibmas (keamanan, ketertiban dalam masyarakat) dengan tugas pokoknya melindungi, mengayomi, melayani masyarakat dan menegakkan hukum (UU No 2 Tahun 2002). Ini menunjukkan bahwa kinerja persoil menjadi aspek penting untuk diperhatikan agar tugas-tugas pokok yang ada di Kepolisian dapat berjalan sesuai dengan koridornya.

Berdasarkan observasi awal yang dilakukan pada Polres Lhokseumawe, sebagian besar personil telah memiliki kinerja yang cukup baik. Akan tetapi, terdapat beberapa personil masih memiliki kinerja di bawah rata-rata. Sebagian personil masih belum bekerja secara efektif dan efisien, yang dapat dilihat dari masih terdapat sedikit keterlambatan dalam penyelesaian tugas. Selain itu, beberapa personil juga masih belum bekerja secara cepat dan fokus, dimana hal tersebut dapat dilihat dari keluhan masyarakat terhadap beberapa personil yang memperlambat urusan-urusan masyarakat di bidang hukum. Hasil observasi awal juga menemukan bahwa sebagian kecil personil masih harus bekerja dengan pengawasan yang tinggi. Hal ini menunjukkan bahwa kinerja personil Polri di Polres Lhokseumawe masih belum optimal.

Permasalahan belum optimalnya kinerja juga diikuti dengan masih rendahnya elemen kepemimpinan transformasional di Polres Lhokseumawe. Berdasarkan hasil observasi awal yang telah dilakukan di Polres Lhokseumawe, Sebagian besar personil telah mampu menyerap nilai visi dan misi Polres Lhokseumawe yang disampaikan oleh pemimpinan, tetapi masih terdapat beberapa personil yang belum mampu menyerapa dan mengimplementasikan visi misi tersebut. Selain itu, sebagian personil juga masih belum bekerja optimal yang menyebabkan harapan/ekspektasi pemimpin terhadap pekerjaan tersebut berkurang. Hal ini menunjukkan bahwa elemen kepemimpinan transformasional di Polres Lhokseumawei masih perlu untuk ditingkatkan.

Faktor lain yang juga menjadi aspek yang belum optimal di Polres Lhokseumawe yaitu tingkat disiplin kerja. Hasil observasi awal yang dilakukan menemukan bahwa sebagian besar personil telah memiliki kedisplinan yang baik, tetapi masih terdapat beberapa personil yang memiliki tingkat kedisiplinan di bawah rata-rata. Sebagian kecil personil Polri di Polres Lhokseumawe masih datang belum tepat waktu, dan masih ditemukannya sebagian kecil Porsenil yang mangkir di saat jam kerja. Sebagian kecil personil berpendapat bahwa jarak rumah yang berada di luar wilayah administrasi Kota Lhokseumawe menjadi faktor yang menyebabkan keterlambatan masuk kerja.

Penulis menduga bahwa belum optimalnya kinerja personil di Polres Lhokseumawe dikarenakan komitmen organisasi yang belum memadai. Hasil observasi awal menemukan bahwa sebagian besar personil Polri telah memiliki komitmen yang baik, tetapi ada beberapa personil yang memiliki komitmen di bawah rata-rata. Masih terdapat sebagian personil yang memiliki konflik internal dengan personil lainnya. Beberapa personil yang memiliki komitmen di bawah rata-rata juga masih belum memiliki rasa bersalah kita mangkir ataupun meninggalkan tugas sebagai Polri.

\section{LANDASAN TEORI DAN HIPOTESIS}

Pengaruh Kepemimpinan Transformasional terhadap Komitmen Organisasi

Kepemimpinan transformasional merupakan kemampuan untuk memberikan inspirasi dan memotivasi pada bawahannya untuk mendapatkan imbalan (Mondiani, 2012). Pentingnya kepemimpinan dalam pencapaian organisasi mengharuskan suatu organisai memperhatikan faktor operasional organisasi (Purnawati et al., 2017). Yukl (2010) berpendapat bahwa menyatakan bahwa pemimpin transformasional adalah pemimpin yang mendorong personilnya untuk memunculkan ide- 
ide baru dan solusi kreatif atas masalah-masalah yang dihadapi. Kepemimpinan transformasional dapat mengembangkan setiap orang menjadi self leadership, dimana kepemimpinan transformasional merupakan pemimpin yang memimpin orang lain untuk memimpin diri mereka sendiri (Mubarak \& Darmanto, 2016). Peningkatan kepemimpinan transformasional akan bedampak kepada kesetiaan anggota organisasi sehingga komitmen organisasi meningkat.

Beberapa riset sebelumnya telah menemukan bahwa kepemimpinan transformasional berpengaruh signifikan terhadap komitmen organisasi. Seperti yang ditemukan oleh Ismail et al. (2011) bahwa tingginya kepemimpinan transformasional akan mampu meningkatkan kinerja secara signifikan. Sementara itu, Kesuma \& Supartha (2016) berhasil membuktikan bahwa kepemimpinan transformasional menjadi faktor yang mendorong peningkatan kinerja secara signifikan. Penelitian di kepolisian pernah dilakukan oleh Setyowati (2015) yang menemukan bahwa gaya kepemimpinan transformasional berpengaruh positif dan signifikan terhadap komitmen organisasi.

Berdasarkan uraian di atas, maka hipotesis pertama yang dapat disusun dalam penelitian ini adalah sebagai berikut:

H1 : Kepemipinan transformasional berpengaruh signifikan terhadap komitmen organisasi personil Polri di Polres Lhokseumawe

\section{Pengaruh Disiplin Kerja terhadap Komitmen Organisasi}

Disiplin pada dasarnya adalah kemampuan untuk mengendalikan diri dan mendukung sesuatu yang telah dibuat dalam menegakkan standar organisasi yang dinyatakan dalam pelaksanaan pedoman manajemen untuk memperkuat organisasi (Manurung \& Riana, 2016). Disiplin kerja menjadi alat yang digunakan para manajer untuk berkomunikasi dengan personil agar mereka bersedia untuk mengubah suatu perilaku serta sebagai suatu upaya untuk meningkatkan kesadaran dan kesediaan seseorang menaati semua peraturan perusahaan dan norma-norma sosial yang berlaku (Mankunegara, 2015). Anggota organisasi yang disiplin tinggi akan membuat mereka menjadi menyatu dengan bagian organisasi dan komitmen organisasi meningkat (Nuraini et al., 2017).

Beberapa studi sebelumnya telah membuktikan bahwa disiplin kerja berpengaruh positif dan signifikan terhadap komitmen organisasi. Nugraha et al. (2017) menemukan bahwa disiplin kerja berpengaruh positif dan signifikan terhadap komitmen organisasi. Hal yang sama juga ditemukan oleh Manurung \& Riana (2016) mendokumentasikan bahwa semakin disiplin seseorang maka komitmen organisasinya akan meningkat secara signifikan. Adapun penelitian pada Personil Polri pernah dilakukan oleh Agung \& Rahardjo (2014) yang menemukan bahwa tingkat kedisiplinan personil memberikan pengaruh positif dan signifikan terhadap komitmen organisasinya.

Berdasarkan uraian di atas, hipotesis kedua yang dapat diajukan dalam penelitian ini berbunyi:

H2 : Disiplin kerja berpengaruh signifikan terhadap komitmen organisasi personil Polri di Polres Lhokseumawe

Pengaruh Kepemimpinan Transformasional terhadap Kinerja Personil

Robins (2006) mengatakan bahwa pemimpin yang menginspirasi pengikut untuk melakukan hal yang melebihi kepentingan pribadi mereka demi kepentingan perusahaan dan mampu memberikan dampak mendalam dan luar biasa kepada para personil. Kepemimpinan transformasional ada sebagai tambahan kepemimpinan transaksional, kepemimpinan ini dapat menghasilkan tingkat kinerja lebih baik, memiliki sifat lebih dari kharisma, memberikan visi dan misi, menanamkan kebanggaan, mengkomunikasikan agar harapan menjadi tinggi, berfokus pada usaha serta menggambarkan maksud penting secara sederhana (Murtiningsih, 2017). Kepemimpimpinan Transformasional meliputi hubungan yang lebih intens antara pemimpin dan personilnya (Septyan et al., 2017). Hubungan yang 
lebih intens dengan personil dapat mempengaruhi personil agar mau menjalankan perintah dengan senang hati tanpa paksaan (Purnawati et al., 2017).

Studi sebelumnya telah menguji pengaruh kepemimpinan transformasional terhadap kinerja dan membuktikan bahwa kepemimpinan transformasional berpengaruh positif terhadap kinerja. Septyan et al. (2017) menemukan bahwa kepemimpinan transformasional menjadi variabel yang memberikan pengaruh positif terhadap kinerja. Sementara itu, Zahabi (2018) menemukan bahwa kepemimpinan pada personil polisi menjadi faktor yang mampu meningkatkan kinerja personil secara signifikan. Penelitian Hefrizon (2014) yang dilakukan pada Satuan Brimob Polda DIY mendokumentasikan bahwa kepemimpinan transformasional memiliki pengaruh positif dan signifikan terhadap kinerja personil Brimob.

Berdasarkan uraian di atas, hipotesis ketiga yang dapat diajukan dalam penelitian ini berbunyi:

H3 : Kepemimpinan transformasional berpengaruh signifikan terhadap kinerja personil Polri di Polres Lhokseumawe

\section{Pengaruh Disiplin Kerja terhadap Kinerja Personil}

Berbagai teori menjelaskan bahwa terdapat hubungan yang signifikan antara variabel disiplin kerja dan kinerja, semakin tinggi disiplin kerja seseorang maka akan semakin tinggi juga kinerjanya. Hasibuan (2012) berargumen bahwa disiplin menjadi kunci keberhasilan suatu organisasi dalam mencapai tujuannya. Disiplin sebagai keadaan ideal dalam mendukung pelaksanaan tugas sesuai aturan dalam rangka mendukung optimalisasi kerja (Rukhyati, 2018). Tinginya disiplin kerja akan meningkatkan kinerja. Uraian di atas menunjukkan bahwa ada pengaruh yang signifikan antara disiplin kerja dengan kinerja personil.

Beberapa studi sebelumnya telah membuktikan bahwa disiplin kerja menjadi faktor yang mampu meningkatkan kinerja individu. Seperti kajian empiris yang dilakukan oleh Rukhyati (2018) yang menemukan bahwa disiplin kerja menjadi faktor yang mempengaruhi kinerja secara signifikan. Selanjutnya, Zahabi (2018) menemukan bahwa semakin disiplin personil maka kinerja personil tersebut akan meningkat. Penelitian yang dilakukan oleh Oktafiani \& Wardhana (2018) juga membuktikan bahwa disiplin kerja memiliki pengaruh positif dan signifikan terhadap kinerja personil Polri.

Berdasarkan uraian di atas, hipotesis keempat yang dapat diajukan dalam penelitian ini berbunyi:

H4 : Disiplin kerja berpengaruh signifikan terhadap kinerja personil Polri di Polres Lhokseumawe

Pengaruh Komitmen Organisasi terhadap Kinerja Personil

Komitmen organisasional dapat dikatakan sebagai sebuah keadaan psikologi yang mengkarakteristikan hubungan personil dengan organisasi atau implikasinya yang mempengaruhi apakah personil akan tetabertahan dalam organisasi atau tidak (Tolis et al., 2017). Komitmen organisasi juga terkait dengan kekuatan identifikasi individu dan keterlibatannya dalam organisasi tertentu (Sudarmanto, 2014). Komitmen organisasi ditunjukkan dalam sikap penerimaan, keyakinan yang kuat terhadap nilai-nilai dan tujuan-tujuan sebuah organisasi demi tercapainya tujuan organisasi (Wibisono, 2018). Komitmen pegawai pada organisasi merupakan dimensi perilaku yang dapat digunakan untuk mengukur dan mengevaluasi kekuatan pegawai dalam bertahan dan melaksanakan tugas dan kewajibannya pada organisasi (Muis et al. 2018).

Beberapa studi sebelumnya telah menemukan bahwa komitmen organisasi berpengaruh signifikan terhadap kinerja. Amirullah et al., (2018) menemukan bahwa komitmen organisasi memberikan dampak positif terhadap kinerja. Ningsih \& Nofrianto (2014) menemukan bahwa komitmen 
organisasi berpengaruh positif dan signifikan terhadap kinerja polisi. Hal yang sama juga ditemukan oleh Bibiharta et al (2018) dimana komitmen organisasi menjadi faktor yang mampu meningkatkan kinerja personil polisis secara signifikan.

Berdasarkan uraian di atas, hipotesis kelima yang dapat diajukan dalam penelitian ini berbunyi:

H5 : Komitmen organisasi berpengaruh signifikan terhadap kinerja personil Polri di Polres Lhokseumawe

Komitmen Organisasi Memediasi Pengaruh Kepemimpinan Transformasional terhadap Kinerja Personil

Individu yang memiliki motivasi dari dalam Komitmen organisasi menjadi elemen penting dalam tercapainya kinerja yang optimal. Komitmen organisasi secara umum dapat diartikan sebagai keterikatan pegawai pada organisasi dimana pegawai tersebut bekerja (Amirullah et al., 2018). Erawati \& Wahyono (2019) menyatakan komitmen organisasi adalah pengikat antara perilaku kedisiplinan individu dengan suatu organisasi, gagasan atau aktualisasi yang diwujudkan dalam mendedikasikan dirinya bagi pencapaian misi organisasi.

Beberapa studi sebelumnya telah menemukan bahwa komitmen organisasi mampu memediasi pengaruh kepemimpinan transformasional terhadap kinerja. Seperti hasil temuan Purnawati et al. (2017) dan Bangun (2017) yang menemukan bahwa komitmen organisasi memberikan efek mediasi secara parsial pada pengaruh kepemimpinan transformasional terhadap kinerja. Kajian lain yang dilakukan oleh Nurdin \& Rohendi (2016) yang menemukan bahwa komitmen organisasi memediasi penuh pengaruh kepemimpinan transformasional terhadap kinerja.

Berdasarkan uraian di atas, maka hipotesis keenam dalam penelitian ini berbunyi:

H6 : Komitmen organisasi memediasi pengaruh kepemimpinan transformasional terhadap kinerja personil Polri di Polres Lhokseumawe

Komitmen Organisasi Memediasi Pengaruh Disiplin Kerja terhadap Kinerja Personil

Disiplin kerja merupakan kebutuhan yang sangat penting untuk pecapaian tujuan organisasi (Amirullah et al., 2018). Selain itu, Luthans (2002) berpendapat bahwa komitmen organisasi sebagai sebuah sikap yang merefleksikan loyalitas pegawai kepada organisasi dan merupakan suatu proses berkelanjutan dimana anggota organisasi mengungkapkan perhatian mereka terhadap organisasi, terhadap keberhasilan organisasi serta kemajuan yang berkelanjutan. Komitmen organisasi juga menjadi elemen perantara untuk meningkatkan kinerja (Junaedi et al., 2013).

Beberapa studi sebelumnya juga telah membuktikan bahwa komitmen organisasi memediasi pengaruh disiplin kerja terhadap kinerja. Seperti riset yang telah dilakuka oleh Rahmawan et al. (2016) menemukan bahwa komitmen organisasi memediasi pengaruh disiplin kerja terhadap kinerja secara full mediation. Sementara itu, temuan Erawati dan Wahyono (2019) membuktikan bahwa bahwa komitmen organisasi memediasi pengaruh disiplin kerja terhadap kinerja secara partial mediation.

Berdasarkan uraian di atas, maka hipotesis keenam dalam penelitian ini berbunyi:

H7 : Komitmen organisasi memediasi pengaruh disiplin kerja terhadap kinerja personil Polri di Polres Lhokseumawe

\section{METODE PENELITIAN}

Objek di dalam penelitian ini adalah para personil dari Polres Lhokseumawe. Sementara itu, penelitian ini dilakukan di Kantor Kepolisian Resor Lhokseumawe yang berada di Jalan MedanBanda Aceh, Cunda, Kecamatan Muara Dua Kota Lhokseumawe. 
Adapun populasi dalam penelitian ini adalah seluruh Personil Polri yang bertugas di Polres Lhokseumawe, yaitu berjumlah 315 personil. Sementara itu, Dalam penelitian ini penentuan besarnya jumlah sampel yang diambil oleh peneliti menggunakan sampel Proportioned Random Sampling. Untuk menentukan jumlah sampel dalam penelitian ini, maka digunakan Rumus Slovin dengan tingkat kesalahan 5\% yang dapat dilihat di bawah ini (Sugiyono, 2016):

\section{6}

Dimana :

$$
\begin{array}{lll}
\mathrm{n} & = & \text { ukuran sampel } \\
\mathrm{N} & = & \text { ukuran populasi } \\
\mathrm{e} & = & \text { Tingkat error }(5 \%)
\end{array}
$$

Adapun distribusi sampel secara persentasi jumlah personil dapat dilihat pada tabel di bawah ini:

\section{Tabel 1}

Jumlah Populasi dan Sampel

No Nama Satuan Jumlah Populasi

(Orang) Jumlah Sampel

(Orang)

$\begin{array}{lllll}1 & \text { Bag Ops } & 11 & 6 \\ 2 & \text { Bag Ren } & 7 & 4 & \\ 3 & \text { Bag Sumda } & 20 & 11 & \\ 4 & \text { Sat Sabhara } & 77 & 43 & \\ 5 & \text { Sat Reskim } & 46 & 26 & \\ 6 & \text { Sat Res Narkoba } & 21 & 12 \\ 7 & \text { Sat Intelkam } & 27 & 15 & \\ 8 & \text { Sat Bimnas } & 7 & 4 \\ 9 & \text { Sat Lantas } & 44 & 24 \\ 10 & \text { Sat Tahti } & 9 & 5 \\ 11 & \text { Sat Pol Air } & 8 & 4 \\ 12 & \text { Sie Was } & 4 & 2 \\ 13 & \text { Sie Propam } & 11 & 6 \\ 14 & \text { Sie Keu } & 3 & 2 \\ 15 & \text { Sie UM } & 5 & 3 \\ 16 & \text { Sie Ti Pol } & 5 & 3 \\ 17 & \text { SPKT 10 } & 6 & \end{array}$

Total Personil 315 Orang 176 Orang

Sumber : Bag Sumda Polres Lhokseumawe, 2019

Definisi operasional dan indikator yang digunakan dalam penelitian ini untuk semua variabel adalah sebagai berikut:

Tabel 2

Definisi Operaional Variabel

No Variabel Definisi Operasional Indikator Skala 
$1 \quad$ Kepemimpinan Transformasional

(KT) Sikap kepemimpinan personil Polri yang mempunyai kekuatan untuk mempengaruhi bawahan dengan cara-cara tertentu. $\quad 1$. Pengartikulasian suatu visi

2. Pemupukan penerimaan terhadap sasaran kelompok

3. Harapan-harapan terhadap kerja yang tinggi

4. Pemberian dukungan individual

(Sholeh, 2017)

Interval

2 Disiplin Kerja

(DK)

tindakan manajemen untuk mendorong para anggota memenuhi tuntutan berbagai ketentuan yang harus ditaati dan standar yang harus dipenuhi terkait dengan ketepatan waktu dan tanggung jawab personil Polri

1. Hadir tepat waktu

2. Jam kerja efektif dan efisien

3. Semangat kerja

4. Sikap kerja yang baik

5. Kreatif dan inovatif

(Harlie, 2010)

Interval

3 Komitmen Organisasi

(KO)

Sikap yang menggambarkan sejauh mana personil mengenal dan terikat pada tempat dimana personil ditugaskan 1 . Keinginan untuk tetap bertahan dalam organisasi

2. Kesamaan dengan nilai-nilai organisasi

3. Kesamaan dengan tujuan organisasi

4. Keinginan berusaha keras demi kesuksesan organisasi

(Anam 2017) Interval

$4 \quad$ Kinerja Personil

(KP) ukuran kesuksesan personil Polri dalam melaksanakan suatu pekerjaan $1 . \quad$ Kualitas

2. Kuantitas

3. Ketepatan waktu

4. Efektifitas

5. Kemandirian

6. Komitmen

(Bernardin, 2007) Interval

Metode analisis data yang digunakan di dalam penelitian ini adalah analisis SEM (Structural Equation Modelling) yang dioperasionalkan melalui program AMOS (Analysis of Moment Structure). Ghozali (2011) berpendapat bahwa SEM (Structural Equation Modelling) merupakan gabungan dari dua metode statistik yang dikembangkan di ilmu psikologi dan psikometri serta modal persamaan simultan (Simultaneous Equation Modeling) yang dikambangkan di ekonometrika.

Adapun bentuk diagram alur full model dengan variabel mediasi dalam penelitian ini dapat dilihat pada gambar di bawah ini: 


\section{Gambar 1 Full Model Penelitian}

Berdasarkan gambar di atas, maka Structural Equation atau persamaan structural dirumuskan untuk menyatakan hubungan kausalitas antar berbagai konstruk. Rumus yang dikembangkan adalah seper terlihat di bawah ini:

$\mathrm{KO}=\mathrm{b} 1 \mathrm{KT}+\mathrm{b} 2 \mathrm{DK}+\mathrm{z} 1$

$\mathrm{KP}=\mathrm{b} 1 \mathrm{KT}+\mathrm{b} 2 \mathrm{DK}+\mathrm{b} 3 \mathrm{KO}+\mathrm{z} 2$

\section{Keterangan:}

$\mathrm{KO}=$ Komitmen Organisasi

$\mathrm{KP}=$ Kinerja Personil

$\mathrm{b} 1-\mathrm{b} 3=$ Koefisien Regresi

$\mathrm{KT}=$ Kepemimpinan Transformasional

$\mathrm{DK}=$ Disiplin Kerja

$\mathrm{z} 1-\mathrm{z} 2=\quad$ Error term

\section{HASIL PENELITIAN DAN PEMBAHASAN}

Analisis Deskriptif Responden

Berdasarkan usianya ditemukan bahwa Personil berusia 19-28 tahun sebanyak 9\%, personil berusia 29-38 tahun sebanyak 43\%, personil berusia 39-48 Tahun sebanyak 38\% dan Polri yang berusia 4958 tahun sebanyak 10\%. Hasil ini menunjukkan bahwa personil Polres Lhokseumawe didominasi oleh personil yang berusia 29-38 tahun. Hal ini dikarenakan usia di atas 29 tahun merupakan usia yang produktif, dimana seseorang telah mampu memiliki jiwa kepemimpinan yang baik serta memiliki kodisi fisik yang masih energik dan aspek tersebut sangat dituntut dalam profesi sebagai polisi.

Berdasarkan gender, ditemukan bahwa responden perempuan dalam penelitian ini sebanyak $11 \%$, sedangkan responden laki-laki sebanyak 89\%. Ini menunjukkan bahwa personil Polres Lhokseumawe didominasi oleh personil laki-laki. Hal ini dikarenakan profesi polisi lebih menuntut ketanggasan, kekuatan dan ketelitian serta keuletan dan kepribadian yang keras, dimana sifat-sifat tersebut lebih dominan terdapat pada laki-laki.

Berdasarkan status perkawinan, ditemukan bahwa terdapat $93 \%$ responden yang telah menikah dan $6 \%$ responden yang belum menikah, serta hanya terdapat $1 \%$ duda/janda. Ini menunjukkan bahwa personil Polres Lhokseumawe didominasi oleh personil yang telah menikah. Hal ini dikarenakan personil yang telah menikah lebih diominan memiliki kinerja yang lebih tinggi kerana tuntutan dan tanggung jawab setelah menikah lebih tinggi, sehingga hal tersebut mendorong kinerja personil Polri menjadi harul lebih baik.

Berdasarkan tingkat pendidikan terakhir, ditemukan bahwa 52\% responden memiliki tingkat pendidikan SMA/sederajat, 44\% responden memiliki tingkat pendidikan sarjana, 3\% responden memiliki tingkat pendidikan diploma semetara hanya $1 \%$ responden yang memiliki jenjang pendidikan pascasarjana. Ini menunjukkan bahwa personil Polres Lhokseumawe didominasi oleh tamatan SMA/Sederajat. Hal ini dikarenakan minimal pendidikan untuk polisi di Indonesia haruslah tamatan SMA/Sederajat.

Berdasarkan masa kerjanya, personil dengan masa kerja di bawah 9 tahun sebanyak 45\%, masa kerja 10-19 tahun sebanyak 24\%, masa kerja 20-29 tahun sebanyak 22\%, masa kerja 30-39 tahun sebanyak 
9\%. Hasil ini menunjukkan bahwa personil Polri di Polres Lhokseumawe didominasi oleh personil yang memiliki masa kerja dibawah 9 tahun. Hal ini dikarenakan bnayaknya personil Polres Lhokseumawe yang masih muda dan terbilang baru dan baru memiliki masa kerja yang kurang dari 9 tahun.

Uji Validitas dan Reliabilitas

Uji Validitas

Dalam SEM, pengujian validitas dilakukan dengan Confirmatory Factor Analysis (CFA) masingmasing konstruk, yaitu dengan melihat nilai Loading Factor dari indikator yang digunakan. Ghozali (2011) berpendapat bahwa indikator dikatakan valid apabila nilai loading factor berada lebih besar dari 0,60. Adapun hasil CFA untuk setiap variabel yang digunakan dalam penelitian ini adalah sebagai berikut:

1. CFA Kepemimpinan Transformasional

Hasil pengujian CFA untuk indikator kepemimpinan transformasional dapat dilihat pada gambar di bawah ini:

\section{Gambar 2 CFA Kepemimpina Transformasional}

Berdasarkan Gambar 5.6, terlihat bahwa seluruh indikator yang digunakan untuk mengukur variabel kepemimpinan transformasionaldalam penelitian ini berada di atas 0.60 , sehingga dapat disimpulkan bahwa indikator-indikator tersebut telah valid.

\section{CFA Disiplin Kerja}

Hasil Uji CFA untuk indikator disiplin kerja dalam penelitian ini dapat dilihat pada gambar di bawah ini:

\section{Gambar 3 CFA Disiplin Kerja}

Berdasarkan Gambar di atas, terlihat bahwa seluruh indikator yang digunakan untuk mengukur variabel disiplin kerja dalam penelitian ini berada di atas 0.60, sehingga dapat disimpulkan bahwa indikator-indikator tersebut telah valid.

\section{CFA Komitmen Organisasi}

Hasil pengujian CFA untuk indikator variabel Komitmen Organisasi dapat dilihat pada gambar di bawah ini:

\section{Gambar4 CFA Komitmen Organisasi}

Berdasarkan Gambar di atas, terlihat bahwa seluruh nilai loading factor berada di atas nilai 0.60 yang menunjukkan bahwa indikator yang digunakan telah valid.

4. CFA Kinerja Personil

Hasil pengujian CFA untuk kinerja personil dalam penelitian ini dapat dilihat pada gambar di bawah ini: 


\section{Gambar 5 CFA Kinerja Personil}

Berdasarkan gambar di atas, seluruh indikator kinerja personil memiliki nilai loading factor di atas 0,60 sehingga dapat disimpulkan bahwa seluruh indikator telah valid.

Uji Reliabilitas

Uji reliabilitas dilakukan dengan tiga cara, yaitu construct reliability (CR), variance extracted (VE) dan descriminant validity (DV). Hasil pengujian reliabilitas dalam penelitian ini disajikan pada tabel berikut:

Tabel 3

Uji Reliabilitas

No Variabel (CR) (VE) (DV)

$1 \quad$ Kepemimpinan Transformasional $\quad 0,887 \quad 0,666 \quad 0,816$

$2 \quad$ Disiplin Kerja 0,900 0,643 0,802

$3 \quad$ Komitmen Organisasi 0,825 $0,544 \quad 0,737$

$4 \quad$ Kinerja Personil $\quad 0,890 \quad 0,519 \quad 0,721$

Sumber : Data Diolah, 2019

Berdasarkan Tabel 3, ditemukan bahwa seluruh variabel memiliki nilai CR yang berada di atas nilai 0,70 dan nilai VE berada di atas 0,50. Dengan demikian, keseluruhan konstruk dalam penelitian ini adalah reliabel sehingga model yang dibentuk adalah layak untuk digunakan.

Uji Asumsi SEM

1. Ukuran Sampel

Pada analisis SEM, ukuran sampel yang sesuai adalah 100-200 (Hair et al., 1999). Dalam penelitian ini, banyaknya sampel adalah 176 Personil Polri. Setalah dilakukan pengujian, tidak terdapat outlier data pada jawaban seluruh responden, sehingga sampel tetap sebanyak 176 Personil Polri. Hal ini menunjukkan bahwa penelitian ini memiliki ukuran sampel yang cukup dan susuai untuk dianalisis secara SEM.

\section{Uji Normalitas}

Dalam penelitian ini, evaluasi normalitas dilakukan dengan menggunakan critical ratio skewness dan kurtosis value sebesar $\pm 2,58$. Data dapat disimpulkan normal jika nilai nilai critical ratio skewness atau critical ratio kurtosisi memiliki nilai mutlak antara $-2,58$ sampai $+2,58$. Hasil uji normalitas dalam penelitian ini dapat dilihat pada Tabel 4 berikut:

Tabel 4

Uji Normalitas

Variable $\min \max$ skew c.r. kurtosis c.r.

$\begin{array}{lllllll}\text { KP6 } & 1,000 & 5,000 & -, 335 & -1,812 & -, 881 & -2,197\end{array}$

$\begin{array}{lllllll}\text { KP5 } & 1,000 & 5,000 & -, 216 & -1,168 & -, 998 & -2,578\end{array}$

KP4 $\quad 1,000 \quad 5,000 \quad-, 410 \quad-2,220 \quad-, 923 \quad-2,499$

$\begin{array}{lllllll}\mathrm{KP} 3 & 1,000 & 5,000 & -, 414 & -2,241 & -, 789 & -2,137\end{array}$

$\begin{array}{lllllll}\mathrm{KP} 2 & 1,000 & 5,000 & -, 493 & -2,672 & -, 917 & -2,413\end{array}$

$\begin{array}{lllllll}\text { KP1 } & 1,000 & 5,000 & -, 299 & -1,617 & -, 945 & -2,558\end{array}$

$\begin{array}{lllllll}\text { KO4 } & 1,000 & 5,000 & -, 119 & -, 646 & -, 924 & -2,429\end{array}$

$\begin{array}{lllllll}\text { KO3 } & 1,000 & 5,000 & -, 134 & -, 723 & -, 932 & -2,538\end{array}$

$\begin{array}{lllllll}\mathrm{KO} 2 & 1,000 & 5,000 & -, 256 & -1,385 & -, 919 & -2,428\end{array}$ 


\begin{tabular}{|c|c|c|c|c|c|c|}
\hline KO1 & 1,000 & 5,000 &,- 316 & $-1,711$ &,- 922 & $-2,498$ \\
\hline DK5 & 1,000 & 5,000 &,- 404 & $-2,188$ &,- 921 & $-2,516$ \\
\hline DK4 & 1,000 & 5,000 &,- 328 & $-1,777$ &,- 912 & $-2,487$ \\
\hline DK3 & 1,000 & 5,000 &,- 386 & $-2,088$ &,- 780 & $-2,132$ \\
\hline DK2 & 1,000 & 5,000 &,- 149 &,- 807 &,- 989 & $-2,570$ \\
\hline DK1 & 1,000 & 5,000 &,- 424 & $-2,297$ &,- 992 & $-2,577$ \\
\hline KT4 & 1,000 & 5,000 & ,005 & ,028 &,- 971 & $-2,531$ \\
\hline KT3 & 1,000 & 5,000 & 078 & ,422 &,- 981 & $-2,562$ \\
\hline KT2 & 1,000 & 5,000 & 159 & 861 &,- 770 & $-2,120$ \\
\hline KT1 & 1,000 & 5,000 &,- 221 & $-1,198$ &,- 771 & $-2,123$ \\
\hline \multicolumn{6}{|c|}{ Multivariate } & 3,928 \\
\hline
\end{tabular}

Sumber : Data Diolah, 2019

Berdasarkan Tabel 4 di atas, terlihat bahwa tidak terdapat nilai critical ratio skewness yang berada diluar rentang $\pm 2,58$. Dengan demikian, dapat disimpulkan bahwa keseluruhan data terdistribusi secara normal secara unvariate. Selanjutnya, nilai multivariate pada critical ratio kurtosis juga berada di rentang $\pm 2,58$ yaitu sebesar 2.508, sehingga dapat disimpulkan bahwa baik secara unvariate maupun multivariate data dalam penelitian ini berdistribusi secara normal.

\section{Uji Outlier Data}

Data ekstrim (outlier) adalah observasi yang muncul dengan nilai-nilai ekstrim., karena kombinasi karakteristik yang unik dan terlihat sangat jauh berbeda dengan observasi-observasi lainnya (Ferdinand, 2014). Dalam penelitian ini, pengujian outlier data dilakukan dengan uji Mahalanobis dsquared, dengan membandingkan nilai p1 dan p2. Nilai p1 atau p2 di atas, 0,05 menunjukkan bahwa tidak terdapat outlier data dalam suatu penelitian. Hasil penelitian ini menemukan seluruh responden memiliki nilai $\mathrm{p} 1$ atau $\mathrm{p} 2$ di atas 0.05 sehingga dapat disimpulkan bahwa tidak terjadi outlier data dalam penelitian ini.

\section{Uji Multikolinearitas dan Singularitas}

Asumsi multikolinearitas mengharuskan tidak adanya korelasi yang sempurna atau besar di antara variabel-variabel independen. Hal ini dikarenakan variabel Model SEM sudah dikenakan matriks sebesar 1, maka semua pembobotan regresi yang dibakukan harus berada dalam cakupan plus atau minus 1. Dalam penelitian ini, deteksi multikolinearitas menggunakan nilai Determinan of Sampple Covariance Matrix, dimana nilai Determinan of Sampple Covariance Matrix yang menjauh dari 0 menunjukkan bahwa tidak terdapat multikolinearitas antar variabel endogen.

Penelitian ini menemukan bahwa nilai Determinan of Sample Covariance Matrix sebesar 0.117 dimana nilai tersebut terbilang begitu jauh dari 0 , maka dapat dikatakan bahwa tidak terdapat gejala multikolineritas dalam penelitian ini.

\section{Uji Kesesuaian Model}

1. Full Model sebelum Modifikasi

Uji Full Model sebelum modifikasi bertujuan untuk melihat sejauh mana model dasar yang dibentuk dalam penelitian ini memenuhi kriteria goodness of fit (GOF), sehingga model dapat menggambarkan fenomena penelitian tanpa adanya modifikasi. Hasil Uji Full Model sebelum modifikasi dapat dilihat pada gambar di bawah ini: 
Gambar 6 Full Model sebelum Modifikasi

Sumber : Data Diolah (2019)

Berdasarkan Gambar 6, ditemukan bahwa secara umum model penelitian belum memenuhi kriteria Goodness of Fit Index, dimana terlihat jelas bahwa nilai p-value sebesar 0,000 yang berada di bawah 0,05. Hal tersebut dapat dilihat sebagai berikut:

Tabel 5

Goodness of Fit untuk Full Model Sebelum Modifikasi

\begin{tabular}{|c|c|c|c|c|c|}
\hline No & Kriteria & Nilai Diharapk & Kan & Nilai Hasil & Kesimpulan \\
\hline 1 & Chi Square & Diharapkan K & ecil & 249,333 & Baik \\
\hline 2 & $(\mathrm{GFI})>0,90$ & 0.875 Margir & & & \\
\hline 3 & $(\mathrm{AGFI})$ & $>0,90 \quad 0.838$ & \multirow{3}{*}{\multicolumn{2}{|c|}{ Marginal }} & \\
\hline 4 & $(\mathrm{TLI})>0,90$ & 0.933 Baik & & & \\
\hline 5 & $(\mathrm{CFI})>0.90$ & 0.943 Baik & & & \\
\hline 6 & (RMSEA) & $\leq 0,08 \quad 0.064$ & \multicolumn{2}{|l|}{ Baik } & \\
\hline 7 & CMIN/DF & 1.708 & \multirow{2}{*}{\multicolumn{2}{|c|}{ Baik }} & \\
\hline 8 & p-value $>0,05$ & 0.000 Buruk & & & \\
\hline
\end{tabular}

Sumber : Data Diolah, 2019

Berdasarkan Tabel 5, terlihat bahwa nilai GFI dan AGFI dalam penelitian ini masih marginal, kemudian GOF pada Full Model masih belum dapat diterima dikarenakan nilai p-value jauh berada di 0,05. Maka dari itu, Full Model memerlukan modifikasi dengan unobserve variable menggunakan petunjuk covariances sesuai dengan hasil output pada Modification Indices (Lampiran 13).

Adapun petunjuk modifikasi berdasarkan hasil analisis Modification Indices dapat dilihat pada tabel berikut:

Tabel 6

Modification Indice

\begin{tabular}{|c|c|c|c|}
\hline & & & M.I. Par Change \\
\hline e18 & $\langle-\rangle$ & e19 & $21,0540,191$ \\
\hline e17 & $\langle-->$ & e19 & $7,731-0,154$ \\
\hline e16 & $\langle--\rangle$ & e18 & $-0,162$ \\
\hline e16 & $<-->$ & e17 & $13,8360,247$ \\
\hline e14 & $<-->$ & e19 & $12,125-0,207$ \\
\hline e14 & $\langle-->$ & e17 & $8,450 \quad 0,190$ \\
\hline e14 & $<-->$ & e16 & $13,3720,260$ \\
\hline e10 & $\langle-->$ & $\mathrm{e} 12$ & $5,124 \quad 0,210$ \\
\hline e8 & $\langle-->$ & e9 & 0,116 \\
\hline e6 & $\langle-->$ & e9 & $-0,204$ \\
\hline e6 & $\langle--\rangle$ & e7 & $20,1610,286$ \\
\hline
\end{tabular}

Sumber : Data Diolah, 2019

Iskandar, Faisal Matriadi, Aiyub 


\section{2. $\quad$ Full Model setelah Modifikasi}

Pengujian full model setelah modifikasi dilakukan dengan cara menghubungkan antar error pada setiap indikator berdasarkan hasil Modification Indices. Modifikasi dilakukan sebanyak 7 kali dengan tujuan untuk menaikkan nilai GOF agar model layak untuk diestimasikan. Hasil uji full model setelah modifikasi dapat dilihat pada gambar di bawah ini:

Gambar 7 Full Model setelah Modifikasi

Sumber : Data Diolah (2019)

Berdasarkan Gambar 7, terlihat bahwa terjadi peningkatan nilai GOF yang signifikan, dimana nilai pvalue menjadi 0,134 yang berada di atas nilai toleransi kesalahan dalam penelitian ini $(0,05)$, sehingga menunjukkan bahwa model dapat diterima dan diestimasikan. Ringkasan nilai GOF setelah modifikasi model dapat dilihat pada tabel 5.18 di bawah ini:

\section{Tabel 7}

Goodness of Fit untuk Full Model Setelah Modifikasi

\begin{tabular}{|c|c|c|c|c|c|c|}
\hline No & Kriteria & Nilai I & Diharapl & kan & Nilai Hasil & Kesimpulan \\
\hline 1 & Chi Square & Dihara & pkan K & ecil & 153.343 & Baik \\
\hline 2 & $(\mathrm{GFI})>0,90$ & 0.919 & Baik & & & \\
\hline 3 & $(\mathrm{AGFI})>0,90$ & 0.886 & Margir & & & \\
\hline 4 & $(\mathrm{TLI})>0,90$ & 0.987 & Baik & & & \\
\hline 5 & $>0.90$ & 0.990 & Baik & & & \\
\hline 6 & (RMSEA) & $\leq 0,08$ & 0.028 & Baik & & \\
\hline 7 & CMIN/DF & $\leq 2$ & 1.136 & Baik & & \\
\hline 8 & $\mathrm{p}$-value $>0,05$ & 0.134 & Baik & & & \\
\hline
\end{tabular}

Sumber : Data Diolah, 2019

Berdasarkan Tabel 7, terlihat bahwa nilai GFI sudah berubah dari kategori marginal menjadi baik, sedangkan nilai AGFI masih berada pada posisi marginal, tetapi angkanya sudah bergerak hingga mendekati angka 9. Selanjutnya, hasil full model setelah dilakukan modifikasi memiliki nilai p-value yang berada di atas 0,134 sehingga model ini dapat diterima dan layak untuk diestimasikan.

Estimasi Model dan Pengujian Hipotesis

Berdasarkan hasil Full Model setelah modifikasi, maka nilai koefisien, critical ratio dan p-value antar variabel eksogen terhadap variabel endogen dapat dilihat sebagai berikut:

Tabel 8

Estimasi Structural Equation Modeling

\begin{tabular}{lllllll}
\multicolumn{7}{c}{ Estimate } \\
\multicolumn{2}{l}{ Standardize) } & S.E. & C.R. & P \\
KO & $<---$ & KT & 0,222 & 0,060 & 2,553 & 0,011 \\
KO & $<---$ & DK & 0,266 & 0,076 & 2,942 & 0,003 \\
KP & $<---$ & KO & 0,301 & 0,106 & 3,027 & 0,002 \\
KP & $<---$ & KT & $-0,182$ & 0,051 & $-1,105$ & 0,095 \\
KP & $<---$ & DK & 0,241 & 0,081 & 2,653 & 0,008
\end{tabular}

Sumber : Data Diolah, 2019 
Berdasarkan hasil estimasi model yang disajikan pada Tabel 5.19, maka hasil persamaan jalur adalah sebagai berikut:

$\mathrm{KO}=0,222 \mathrm{KT}+0,266 \mathrm{DK}$

$\mathrm{KP}=-0,182 \mathrm{KT}+0,241 \mathrm{DK}+0,301 \mathrm{KO}$

Adapun bentuk pengaruh dan pengujian hipotesis antara variabel eksogen dengan variabel endogen adalah sebagai berikut:

1. Pengaruh Kepemimpinan Transformasional terhadap Komitmen Organisasi

Berdasarkan hasil analisis SEM, nilai koefisien kepemimpinan transformasional (KT) terhadap komitmen organisasi (KO) sebesar 0,222 (22,2\%) yang menunjukkan bahwa ketika kepemimpinan transformasional naik $1 \%$, maka komitmen organisasi akan meningkat sebesar $22,2 \%$. Selanjutnya nilai tersebut signifikan secara statistik dengan p-value sebesar 0,011, dimana nilai tersebut berada di bawah nilai toleransi kesalahan dalam penelitian ini $(0,05)$, sehingga $\mathrm{H} 1$ diterima yang artinya kepemimpinan tranasformasional berpengaruh positif terhadap komitmen organisasi pada Personil Polri di Polres Lhokseumawe.

\section{2. $\quad$ Pengaruh Disiplin Kerjaterhadap Komitmen Organisasi}

Berdasarkan hasil analisis SEM, nilai koefisien disiplin kerja (DK) terhadap komitmen organisasi (KO) sebesar 0,266 (26,6\%) yang menunjukkan bahwa ketika disiplin kerjanaik 1\%, maka komitmen organisasi akan meningkat sebesar $26,6 \%$. Selanjutnya nilai tersebut signifikan secara statistik dengan p-value sebesar 0,003, dimana nilai tersebut berada di bawah nilai toleransi kesalahan dalam penelitian ini $(0,05)$, sehingga $\mathrm{H} 2$ diterima yang artinya disiplin kerja berpengaruh positif terhadap komitmen organisasi pada Personil Polri di Polres Lhokseumawe.

\section{Pengaruh Kepemimpinan Transformasional terhadap Kinerja Personil}

Berdasarkan hasil analisis SEM, nilai koefisien kepemimpinan transformasional (KT) terhadap kinerja personil (KP) sebesar -0,128 (12,8\%) yang menunjukkan bahwa ketika kepemimpinan transformasionalnaik 1\%, maka kinerja personil akan menurun sebesar 12,8\%. Akan tetapi, nilai tersebut tidak signifikan secara statistik, dimana nilai $\mathrm{p}$-value hanya sebesar 0,095 yang berada di atas nilai toleransi kesalahan dalam penelitian ini $(0,05)$, sehingga $\mathrm{H} 3$ ditolak yang artinya kepemimpinan transformasional tidak berpengaruh signifian terhadap kinerja Personil Polri di Polres Lhokseumawe.

\section{Pengaruh Disiplin Kerjaterhadap Kinerja Personil}

Berdasarkan hasil analisis SEM, nilai koefisien disiplin kerja(DK) terhadap kinerja personil (KP) sebesar 0,241 (24,1\%) yang menunjukkan bahwa ketika disiplin kerjanaik 1\%, maka kinerja personil akan meningkat sebesar $24,1 \%$. Selanjutnya, nilai koefisien tersebut tergolong signifikan secara statistik denganp-value sebesar 0,008 yang berada di bawah nilai toleransi kesalahan dalam penelitian ini $(0,05)$, sehingga $\mathrm{H} 4$ diterima yang artinya disiplin kerja berpengaruh posiitf terhadap kinerja Personil Polri di Polres Lhokseumawe.

\section{Pengaruh Komitmen Organisasi terhadap Kinerja Personil}

Berdasarkan hasil analisis SEM, nilai koefisien komitmen organisasi(KO) terhadap kinerja personil (KP) sebesar 0,301 (30,1\%) yang menunjukkan bahwa ketika komtimen organisasinaik 1\%, maka kinerja personil akan meningkat sebesar 30,1\%. Selanjutnya, nilai koefisien tersebut tergolong signifikan secara statistik dengan p-value sebesar 0,002 yang berada di bawah nilai toleransi 
kesalahan dalam penelitian ini $(0,05)$, sehingga H5diterima yang artinya komitmen organisasi berpengaruh posiitf terhadap kinerja Personil Polri di Polres Lhokseumawe.

\subsubsection{Pengaruh Total, Langsung dan Tidak Langsung}

Untuk melihat efek mediasi, maka terlebih dahulu akan dilihat seberapa besar pengaruh langsung, pengaruh tidak langsung serta pengaruh total untuk pengaruh kepemimpinan transformasional dan disiplin kerja terhadap komitmen organisasi dan kinerja personil, dimana hasilnya dapat dilihat sebagai berikut:

Tabel 9

Pengaruh Lansung, Tidak lansung dan Total Pengaruh

DK KT KO KP

Total Pengaruh

$\begin{array}{lllll}\text { KO } & 0,266 & 0,222 & ---- & --- \\ \text { KP } & 0,322 & -0,115 & 0,301 & ----\end{array}$

Pengaruh Langsung

KO $\quad 0,266 \quad 0,222 \quad----\quad----$

KP $\quad 0,241 \quad-0,182 \quad 0,301 \quad----$

Pengaruh Tidak Langsung

KO ---- $\quad----\quad----\quad----$

KP $\quad 0,080 \quad 0,067 \quad----\quad----$

Sumber : Data Diolah, 2019

Berdasarkan Tabel 9, maka pengaruh langsung variabel eksogen terhadap variabel endogen dalam penelitian ini adalah sebagai berikut:

1. Pengaruh langsung kepemimpinan tranasformasional terhadap komitmen organisasai sebesar $0,222(22,2 \%)$ dan signifikan.

2. Pengaruh langsung disiplin kerja terhadap komitmen organisasai sebesar $0,266(26,6 \%)$ dan signifikan.

3. Pengaruh langsung kepemimpinan tranasformasional terhadap kinerja personil sebesar $-0,182$ $(18,2 \%)$ tetapi tidak signifikan.

4. Pengaruh langsung disiplin kerja terhadap kinerja personil sebesar $0,241(24,1 \%)$ dan signifikan.

5. Pengaruh langsung komitmen organisasi terhadap kinerja personil sebesar $0,301(30,1 \%)$ dan signifikan.

Adapun pengaruh kepemimpinan tranasformasional dan disiplin kerja terhadap kinerja personil secara tidak langsung adalah sebagai berikut:

1. Pengaruh kepemimpinan tranasformasional terhadap kinerja personil melalui komitmen organisasi sebesar $0,067(6,7 \%)$.

2. Pengaruh disiplin kerjaterhadap kinerja personil melalui komitmen organisasi sebesar 0,080 $(8 \%)$.

Adapun total pengaruh kepemimpinan tranasformasional dan disiplin kerja terhadap kinerja personil adalah sebagai berikut:

1. Total pengaruh kepemimpinan transformasional terhadap kinerja personil sebesar $-0,115$ ($11,5 \%)$.

2. Total pengaruh disiplin kerjaterhadap kinerja personil sebesar $0,322(32,2 \%)$. 


\section{Uji Efek Mediasi}

Model mediasi pertama sekali diperkenalkan oleh Baron \& Kenny (1986), menjelaskan prosedur analisis variabel mediator secara sederhana melalui regresi. Intinya, menurut Baron \& Kenny (1986) mensyaratkan bahwa sebuat variabel dapat dikatakan menjadi mediator jika hasilnya adalah Jalur $-\mathrm{c}$ signifikan, Jalur -a signifikan, jalur -b signifikan dan jalur -c' tidak signifikan maka disebut sebagai full mediation. Tetapi jika jalur $-\mathrm{a},-\mathrm{b}$, dan $-\mathrm{c}$ signifikan dan jalur $-\mathrm{c}$ ' signifikan maka disebut dengan partial mediation.

Dalam penelitian ini, terdapat 2 hipotesis pengaruh mediasi yang akan diuji, yaitu H6 dan H7. Adapun hasil pengujian ketiga hipotesis tersebut adalah sebagai berikut:

1. Komitmen Organisasi Memediasi Pengaruh Kepemimpinan Transformasional terhadap Kinerja Personil

Hasil pengujian efek mediasi hubungan kepemimpinan tranasformasional dengan kinerja personil melalui komitmen organisasi tidak dapat memenuhi syarat, dikarenakan jalur $-c$ signifikan tidak berpengaruh signifikan, sehingga nilai p-value untuk pengaruh tidak langsung komitmen organisasi terhadap kinerja tidak diperlu diketahui.Untuk lebih jelasnya, dapat dilihat pada gambar di bawah ini:

Gambar 8 Komitmen Organiasai tidak Memediasi Pengaruh Kepemimpinan Transformasional terhadap Kinerja Personil

Berdasarkan Gambar 8, terlihat bahwa kepemimpinan tranasformasional tidak berpengaruh signifikan terhadap kinerja personil, sehingga tidak memenuhi kriteria untuk pengujian efek mediasi. Maka dari itu, komitmen organisasi tidak mampu memediasi pengaruh kepemimpinan transformasional terhadap kinerja personil, sehingga H6 ditolak.

2. Komitmen Organisasi Memediasi Pengaruh Disiplin Kerja terhadap Kinerja Personil Hasil pengujian efek mediasi hubungan disiplin kerja dengan kinerja personil melalui komitmen organisasi dapat memenuhi syarat, dikarenakan jalur $-\mathrm{a},-\mathrm{b}$ dan $-\mathrm{c}$ signifikan secara statistik. Untuk melihat nilai signifikansi pada jalur -c', maka perhitungan dilakukan menggunakan kalkulator sobel (Lampiran 12). Adapun hasil pengujian mediasi pada Hipotesis 7 adalah sebagai berikut: 


\section{Gambar 9 Komitmen Organisasi Memediasi Pengaruh Disiplin Kerja terhadap Kinerja Personil}

Berdasarkan Gambar 9, terlihat bahwa nilai p-value untuk c' sebesar 0,027, dimana nilai tersebut berada di bawah nilai toleransi kesalahan dalam penelitian ini, yaitu 0,05. Maka dari itu, H7 diterima yang artinya komitmen organisasi memediasi secara parsial pengaruh disiplin kerja terhadap kinerja personil Polri di Polres Lhokseumawe.

Pembahasan

Pengaruh Kepemimpinan Transformasional terhadap Komitmen Organisasi

Hasil penelitian ini membuktikan bahwa kepemimpinan transformasional terhadap komitmen organisasi pada personil Polri di Polres Lhokseumawe. Hal ini menunjukkan bahwa ketika kepemimpinan transformasional naik maka komitmen personil akan meningkat. Ini juga menunjukkan bahwa kepemimpinan transformasional merupakan prediktor komitmen organisasi.

Hasil penelitian ini sejalan dengan temuan Mubarak \& Darmanto (2016) dan Keskes et al. (2018) serta Siswatiningsih (2018) yang menemukan bahwa kepemimpinan transformasional berpengaruh positif dan signifikan terhadap komitmen organisasi. Sementara itu, hasil jawaban responden menunjukkan bahwa nilai rata-rata tertinggi untuk indikator transformasional adalah indikator ke 1 , hal ini menunjukkan bahwa penyampaian visi dan misi oleh pemimpin menjadi elemen yang domininan dalam menjelaskan kepemimpinan transformasional di Polres Lhokseumawe.

Hasil penelitian ini mengindikasikan bahwa semakin tinggi kepemimpinan transformasional maka komitmen organisasi personil juga akan meningkat. Ketika suatu organisasi menerapkan gaya kepemimpinan transformasional yang optimal, maka anggota organisasi akan lebih merasa nyaman dan komitmen terhadap organisasi mejadi bertambah (Purnawati et al., 2017). Mubarak \& Darmanto (2016) berpendapat bahwa kepemiminan transformasional didefinisikan sebagai gaya pemimpin yang membuat anggotanya untuk bisa memimpin dirinya sendiri. Ini menunjukkan bahwa kepemimpinan transformasional menjadi faktor yang dapat meningkatkan komitmen organisasi secara signifikan.

Pengaruh Disiplin Kerja terhadap Komitmen Organisasi

Hasil penelitian ini menemukan bahwa disiplin kerja berpengaruh positif dan signifikan terhadap komitmen organisasi. Hal ini menunjukkan bahwa disiplin kerjamenjadi prediktor dalam meningkatkan komitmen organisasi pada Personil Polri di Polres Lhokseumawe. Hasil penelitian ini juga mendukung studi yang pernah dilakukan oleh Nugraha et al. (2017), Bangun (2017) serta Amirullah et al. (2018)yang menemukan bahwa disiplin kerja berpengaruh positif dan signifikan terhadap komitmen organisasi.

Hasil analisis deskriptif jawaban responden untuk indikator disiplin kerja menunjukkan bahwa indikator ke 5 menjadi indikator dengan nilai rata-rata tertinggi. Hal ini menunjukkan bahwa inovasi dan kreatifitas dalam menyelesaikan tugas menjadi elemen yang paling dominan dalam menjelaskan disiplin kerja personil Polri di Polres Lhokseumawe.

Hasil penelitian ini mengindikasikan bahwa semakin disiplin personil maka komitmen organisasi akan meningkat. Penerapan kedisiplinan dapat menjadi alat dalam meningkatkan perilaku organisasi, serta sebagai suatu upaya untuk meningkatkan kesadaran dan kesediaan seseorang menaati semua peraturan perusahaan dan norma-norma sosial yang berlaku (Mankunegara, 2015). Hal ini menunjukkan bahwa disiplin dapat memberikan efek positif dalam meningkatkan komitmen organisasi.

Pengaruh Kepemimpinan Transformasional terhadap Kinerja Personil 
Hasil penelitian ini menemukan bahwa kepemimpinan transformasional tidak berpengaruh signifikan terhadap kinerja personil. Hal ini menunjukkan bahwa kepemimpinan transformasional bukanlah prediktor dalam meningkatkan kinerja personil, dimana ketika kepemimpinan transformasional naik ataupun turun tidak memberikan dampak terhadap kinerja personil.

Hasil penelitian ini juga sejalan dengan penelitian yang pernah dilakukan oleh Siswatiningsih (2018) serta Nurdin \& Rohendi (2016)yang menemukan bahwa kepemimpinan transformasional tidak berpengaruh signifikan terhadap kinerja. Hasil penelitian ini mengindikasikan bahwa kepemimpinan transformasional tidak berpengaruh signifikan terhadap kinerja. Pada kepemimpinan transformasional, terdapat tiga indikator yang memiliki nilai rata-rata di bawah 2, yaitu indikator pemupukan terhadap sasaran kelompok, harapan terhadap kerja yang tinggi serta dukungan individual, diman rendahnya indikator tersebut membuat kinerja personil belum optimal.

Hasil penelitian ini menunjukkan kepemimpinan transformasional tidak berpengaruh signifikan terhadap kinerja personil. Ini juga dapat dilihat dari rendahnya nilai indikator seperti pemupukan sasaran, harapan kerja yang tinggi serta dukungan individual yang membuat para personil belum mampu meningkatkan kinerjanya. Siswatiningsih (2018) berpendapat bahwa ketika pemupukan sasaran dan harapan kerja dari pemimpin ke bawahan tergolong rendah, maka gaya kepemimpinan transformasional tidak berdampak pada kinerja individu.

Pengaruh Disiplin Kerja terhadap Kinerja Personil

Hasil analisis data yang telah dilakukan menunjukkan bahwa disiplin kerja berpengaruh positif dan signifikan terhadap kinerja personil Polri di Polres Lhokseumawe. Hal ini menunjukkan bahwa semakin disiplin personil maka akan memiliki kinerja yang baik. Selain itu, temuan ini juga membuktikan bahwa disiplin kerja merupakan prediktor dalam meningkatkan kinerja personil.

Hasil penelitian ini sejalan dengan yang ditemukan oleh Bangun (2017), Nugraha et al. (2017) serta Rukhyati (2018) yang menemukan bahwa disiplin kerja berpengaruh positif dan signifikan terhadap kinerja. Disiplin yang baik mencerminkan besarnya rasa tanggung jawab personil terhadap tugastugas yang diberikan kepadanya. Hal ini akan mendorong gairah dan semangat kerja sehingga kinerjanya meningkat. Personil yang disiplin akan mampu bekerja lebih baik dikarenakan kesadarannya akan tugas-tugas, yang artinya kinerja personil juga akan meningkat.

Pengaruh Komitmen Organisasi terhadap Kinerja Personil

Hasil penelitian ini menemukan bahwa komitmen organisasi berpengaruh positif dan signifikan terhadap kinerja personil Polri di Polres Lhokseumawe. Hal ini menunjukkan bahwa semakin tinggi komitmen organisasi maka kinerja personil juga akan meningkat. Selain itu, ini juga menunjukkan bahwa komitmen organisasi menjadi prediktor dalam meningkatkan kinerja personil.

Hasil penelitian ini sejalan dengan yang ditemukan oleh Amirullah et al.(2018), Bangun (2017) serta Nugraha et al. (2017) yang menemukan bahwa komitmen organisasi berpengaruh positif dan signifikan terhadap kinerja. Sementara itu, nilai rata-rata tertinggi untuk indikator komitmen organisasi terdapat pada indikator ke 4, artinya keinginan untuk berusaha dalam mencapai kesuksesan menjadi elemen yang paling menggambarkan komitmen organisasi di Polres Lhokseumawe.

Hasil penelitian ini menunjukkan bahwa semakin tinggi komitmen organisasi, semakin baik pula kinerja personil. Komitmen organisasi yang mencerminkan rasa kecintaan dan kepatuhan individu terhadap organisasinya membuatnya bekerja lebih baik. Begitu juga dengan para Personil Polri, dimana kecintaan terhadap negara membuat personil akan bekerja dengan ikhlas demi terwujudnya visi misi Polri dalam mengayomi masyarakat. Dengan demikian, hal tersebut menunjukkan bahwa komitmen organisasi berpengaruh terhadap kinerja personil.

Komitmen Organisasi Memediasi Pengaruh Kepemimpinan Transformasional terhadap Kinerja Personil 
Berdasarkan hasil penelitian ini, ditemukan bahwa komitmen organisasi tidak memediasi pengaruh kepemimpinan transformasional terhadap kinerja personil Polri di Polres Lhokseumawe. Ini menunjukkan bahwa komitmen organisasi bukanlah perantara pada hubungan kepemimpinan transformasional terhadap kinerja personil Polri.

Hasil penelitian ini sejalan dengan yang ditemukan oleh Siswatiningsih (2018) serta Nurdin \& Rohendi (2016) yang menemukan bahwa komitmen organisasi tidak memediasi pengaruh kepemimpinan transformasional terhadap kinerja personil. Selanjutnya, hasil penelitian ini menunjukkan bahwa peranan komitmen organisasi sebagai mediator belum tercipta, dimana dapat dilihat dari masih rendahnya kepemimpinan transformasional di Polres Lhokseumawe yang membuat komitmen organisasi belum mampu memediasi kepemimpinan transformasional dengan kinerja personil. Personil yang belum mampu merasa dirinya sebagai pemimpin tentunya tidak memiliki komitmen yang tinggi, sehingga tidak berdampak pada peningkatan kinerjanya.

Komitmen Organisasi Memediasi Pengaruh Disiplin Kerja terhadap Kinerja Personil

Hasil penelitian ini menemukan bahwa nilai p-value pada c' sebesar $(0,027)$ dimana nilai tersebut signifikan secara statistik, yang artinya komitmen organisasi memediasi secara parsial pengaruh disiplin kerja terhadap kinerja Personil Polri di Polres Lhokseumawe. Ini juga menunjukkan bahwa hubungan disiplin kerja terhadap kinerja personil dapat dicapai melalui komitmen organisasi yang baik.

Hasil penelitian ini juga sejalan dengan temuan Bangun (2017) yang menemukan bahwa komitmen organisasi memediasi secara parsial pengaruh disiplin kerja terhadap kinerja. Akan tetapi, hasil ini bertolak belakang dengan temuan Nugraha et al. (2017) yang menemukan bahwa komitmen organisasi memediasi secara penuh pengaruh disiplin kerja terhadap kinerja personil. Selain kepemimpinan, disiplin kerja juga mencerminkan besarnya tanggung jawab seseorang terhadap tugastugas yang diberikan kepadanya. Dengan komitmen yang tinggi maka disiplin akan mampu memberikan dampak yang signifikan terhadap semangat dan gairah kerja sehingga berpengaruh pada kinerja seseorang.

\section{KESIMPULAN DAN SARAN} berikut:

Berdasarkan hasil analisis data yang telah dilakukan, maka dapat diambil kesimpulan sebagai

1. Kepemimpinan transformasional berpengaruh positif dan signifikan terhadap komitmen organisasi personil Polri di Polres Lhokseumawe.

2. Disiplin kerja berpengaruh positif dan signifikan terhadap komitmen organisasi personil Polri di Polres Lhokseumawe.

3. Kepemimpinan transformasional tidak berpengaruh signifikan terhadap kinerja personil Polri di Polres Lhokseumawe.

4. Disiplin kerja berpengaruh positif dan signifikan terhadap kinerja personil Polri di Polres Lhokseumawe.

5. Komitmen organisasi berpengaruh positif dan signifikan terhadap kinerja personil Polri di Polres Lhokseumawe.

6. Komitmen organisasi tidak mampu memediasi pengaruh kepemimpinan transformasional terhadap kinerja personil Polri di Polres Lhokseumawe.

7. Komitmen organisasi mampu memediasi secara parsial pengaruh disiplin kerja terhadap kinerja personil Polri di Polres Lhokseumawe. 
Saran

Beberapa saran yang dapat diberikan penulis dari hasil penelitian ini adalah sebagai berikut:

1. Hasil analisis deskriptif jawaban responden menunjukkan bahwa variabel kepemimpinan transformasional memiliki nilai rata-rata terendah pada indikator ke 3, sehingga disarankan kepada para Personil Polri di Polres Lhokseumawe untuk bekerja lebih optimal dan lebih sesuai dengan harapan-harapan pimpinan di Polres Lhokseumawe.

2. Hasil analisis deskriptif jawaban responden menunjukkan bahwa variabel disiplin kerja memiliki nilai rata-rata terendah pada indikator ke 2, sehingga disarankan kepada para pimpinan di Polres Lhokseumawe untuk lebih mengontrol jam kerja personil agar dapat bekerja lebih efektif dan efisien.

3. Hasil analisis deskriptif jawaban responden menunjukkan bahwa variabel komitmen organisasi memiliki nilai rata-rata terendah pada indikator ke 3, sehingga disarankan kepada para Personil Polri untuk lebih menciptakan nilai-nilai kerja yang positif dalam menyelaraskan kesamaan tujuan dengan visi dan misi Polres Lhokseumawe.

4. Hasil analisis deskriptif jawaban responden menunjukkan bahwa variabel kinerja personil memiliki nilai rata-rata terendah pada indikator ke 5, sehingga disarankan kepada pimpinan Polres Lhokseumawe untuk memberikan pelatihan-pelatihan yang dapat meningkatkan kinerja personil agar personil dapat menyelasaikan tugasnya secara mandiri.

5. Disarankan kepada peneliti lainnya untuk menganalisis faktor-faktor lain yang mempengaruhi kinerja personil Polri, seperti lingkungan kerja, pelatihan, remunerasi serta kepuasan kerja agar dapat mengembangkan teori-teori di bidang Manajemen Sumber Daya Manusia.

\section{DAFTAR REFERENSI}

Adil, V. M., Sendow, G. M., \& Lumintang, G. G. (2018). Pengaruh Komitmen Organisasional, Disiplin Kerja dan Kompensasi Non Finansial Terhadap Kinerja Karyawan pada Dinas Ketenagakerjaan dan Transmigrasi Prov. Sulawesi Utara. Jurnal EMBA: Jurnal Riset Ekonomi, Manajemen, Bisnis dan Akuntansi, 6(4).

Agung, M. \& Rahardjo (2014). Pengaruh Disiplin Kerja dan Motivasi terhadap Kinerja Personil Polri pada Polrestabes Kota Bandung. Jurnal Ekonomi dan Manajemen. 2(1)

Amirullah, A., Arifin, A. H., \& Mariyudi, M. (2018). Pengaruh Peran Kepemimpinan, Kepuasan Kerja dan Disiplin Kerja Terhadap Komitmen Organisasi dan Kinerja Pegawai Adminstrasi di Politeknik Negeri Lhokseumawe. Jurnal Manajemen Indonesia (J-MIND), 2(1), 1-17.

Allen, N. J., \& Meyer, J. P. (1990). The measurement and antecedents of affective, continuance and normative commitment to the organization. Journal of occupational psychology, 63(1), 1-18.

Anam, C. (2017). Pengaruh Komitmen Organisasi, Komunikasi Interpersonal dan Kepuasan Kerja Terhadap Organizational Citizenship Behavior Pada Anggota Kepolisian Resort Jombang. MARGIN ECO, 1(1), 17-39.

Antonakis, J., Avolio, B. J., \& Sivasubramaniam, N. (2003). Context and leadership: An examination of the nine-factor full-range leadership theory using the Multifactor Leadership Questionnaire. The leadership quarterly, 14(3), 261-295.

Bakhtiar., Apridar \& Mariyudi (2018). Pengaruh Komunikasi, Kompetensi dan Beban Kerja Terhadap Komitmen Organisasi dan Dampaknya Terhadap Kinerja Guru SMAN Pada UPTD Samudera dan Syamtalira Bayu. Jurnal Manajemen Indonesia. Vol 3. No 1.

Bangun, Nalsali Frisko. (2017). Pengaruh Gaya Kepemimpinan dan Disiplin Kerja terhadap Kinerja Karyawan Melalui Komitmen Organisasional PT Perkebunan Nusantara XIII Kantor Direksi. Jurnal Ekonomi dan Bisnis. Vol 2. No 3. 
Baron, R. M., \& Kenny, D. A. (1986). The Moderator-Mediator Variable Distinction in Social Psychological Research: Conceptual, strategic, and statistical considerations. Journal of personality and social psychology, 51(6), 1173.

Bernardin, H. John. (2007). Human Resources Management, An Experiential. Approach, 3rd edition, McGraw-Hill/Irwin, New York.

Bibitharta, A. W., Bachri, A. A., \& Dewi, M. S. (2019). Pengaruh Komitmen Organisasi dan Kompensasi Terhadap Kinerja Personil Bhayangkara Pembina Keamanan dan Ketertiban Masyarakat (Bhabinkamtibmas) di Polresta Banjarmasin. Jurnal Wawasan Manajemen, 6(2), 187-196.

Cardoso, L., Meireles, A., \& Ferreira Peralta, C. (2012). Knowledge management and its critical factors in social economy organizations. Journal of knowledge management, 16(2), 267-284.

Edy Marheno, Fasochah \& Darsono (2016). Pengaruh Disiplin Kerja Dan Komitmen Organisasi Terhadap Kinerja Pengasuh Dengan Karakteristik Pekerjaan Sebagai Variabel Moderasi Pada Akademi Kepolisian Semarang. Dharma Ekonomi. Vol 2. No 4.

Erawati, A., \& Wahyono, W. (2019). Peran Komitmen Organisasi dalam Memediasi Pengaruh Disiplin Kerja, Motivasi Kerja, dan Self Efficacy Terhadap Kinerja Pegawai. Economic Education Analysis Journal, 8(1), 288-301.

Erna, Mariyudi \& Nurmala. (2018). Pengaruh Kompetensi, Stres Kerja dan Motivasi Kerja Terhadap Kinerja Pegawai Puskesmas di Kabupaten Tengah dengan Kepuasan Sebagai Variabel Intervening. Jurnal Manajemen Indonesia. Vol 3. No 2.

Farahani, M., Taghadosi, M., \& Behboudi, M. 2011. An Exploration of the Relationship between Transformational Leadership and Organizational Commitment: The Moderating Effect of Emotional Intelligence: Case Study in Iran. International Business Research, Vol 4, No 4, pp. 211-217.

Ghozali, Imam. (2011). Model Persamaan Struktural, Konsep dan Aplikasi dengan Program Amos 24. BP UNDIP, Semarang.

Goodwin, V. L., Wofford, J. C., \& Whittington, J. L. (2001). A theoretical and empirical extension to the transformational leadership construct. Journal of Organizational Behavior: The International Journal of Industrial, Occupational and Organizational Psychology and Behavior, 22(7), 759-774.

Griffin (2004). Komitmen Organisasi. Erlangga, Jakarta.

Hasibuan, Melayu S.P. (2005). Manajemen Sumber Daya Manusia. Edisi Revisi. Bumi Aksara. Jakarta.

Harlie M (2010). Pengaruh Disiplin Kerja, Motivasi dan Pengembangan Karier terhadap Kinerja Pegawai Negeri Sipil pada Pemerintah Kabupaten Tabalong di Tanjung Kalimantan Selatan. Jurnal Manajemen dan Akuntansi. Vol 11. No 2.

Hefrizon, H. (2016). Pengaruh Kepemimpinan Transformasional Dan Budaya Organisasi Terhadap Kepuasan Kerja Anggota Kepolisian Di Satuan BRIMOB POLDA DIY. Jurnal Bisnis: Teori dan Implementasi, 5(2), 232-245.

Hilton, T. L. (2015). Effect of burnout and organizational commitment on the turnover intention of clinical laboratory employees in Florida.

Hughes, R.L., Ginnett, R.C., \& Curphy, G.J. 2012. Leadership: Memperkaya Pelajaran dari Pengalaman, Edisi Ketujuh, Jakarta: Salemba Humanika.

Ismail, A., Mohamed, H., Sulaiman, A.Z., Mohamad, M.H., \& Yusuf, M.H. (2011). An Empirical Study of the Relationship between Transformational Leadership, Empowerment and Organizational Commitment. Business and Economics Research Journal, Vol 2, No 1, pp. 89-107.

Junaedi D., Bambang Swasto, \& Hamidah Nayati Utami. (2013). Pengaruh Gaya Kepemimpinan, Keselamatan dan Kesehatan Kerja, Kepuasan Kerja Terhadap Komitmen Organisasional (Studi Pada Karyawan PG. Kebet Baru Malang), Jurnal Profit, Volume 7. No. 1. Hal. 127-136. 
Junus, S. R., \& Suwandi, M. (2017). Pengaruh Motivasi dan Disiplin Kerja Terhadap Kinerja Anggota Polres Tegal Kota. Multiplier, 1(2).

Kaswan, M. M. (2012). Manajemen sumber daya manusia untuk keunggulan bersaing organisasi. Edisi Pertama. Cetakan Pertama. Penerbit Graha Ilmu. Yogyakarta.

Kesuma, Wira, I. G. A., \& Supartha, I. W. G. (2016). Pengaruh Kepemimpinan Transformasional terhadap Komitmen Organisasional dengan Mediasi Organizational Citizenship Behavior dan Kepuasan Kerja. E-Jurnal Manajemen, 5(6).

Keskes, I., Sallan, J. M., Simo, P., \& Fernandez, V. (2018). Transformational leadership and organizational commitment: Mediating role of leader-member exchange. Journal of Management Development, 37(3), 271-284.

Khuntia, R., \& Suar, D. (2004). A scale to assess ethical leadership of Indian private and public sector managers. Journal of business ethics, 49(1), 13-26.

Krishnan, R., Arumugam, N., Chandran, V., \& Kanchymalay, K. (2009). Examining the Relationship between Job Satisfaction and Organizational Citizenship Behavior: A Case Study among Non Academic Staffs in A Public Higher Learning Institution in Malaysia. In Global Business Summit Conference (Vol. 2, No. 43, pp. 221-232).

Kumarawati, N. M. R., Suparta, G., \& Yasa, P. N. S. (2017). Pengaruh Motivasi Terhadap Disiplin dan Kinerja Pegawai Pada Sekretariat Daerah Kota Denpasar. Jurnal Ekonomi \& Bisnis JAGADITHA, 4(2), 63-75.

Kurniawan, Muhammad (2013). Pengaruh Komitmen Organisasi, Budaya Organisasi dan Kepuasan Kerja terhadap Kinerja Organisasi Publik (Studi Empiris pada SKPD Pemerintah Kabupaten Kernci). Jurnal EMBA. Vol 1. No 3.

Kreitner, Robert. (2014). Organizational Behavioral-Ed. 5. Boston : McGraw-Hill.

Lastriani, E. (2014). Pengaruh Disiplin terhadap Kinerja Anggota pada Satlantas Polresta Pekanbaru. Jurnal Ilmiah Ekonomi dan Bisnis Unilak, 11(2).

Luthans, F. (2006). Organizational Behaviour, Ninth Edition, USA: McGraw-Hill Companies Inc Mondiani, Tria. (2012). Pengaruh Kepemimpinan Transformasional dan Kompensasi Terhadap Kinerja Karyawan PT. PLN (PERSERO) UPJ SEMARANG. Jurnal Administrasi Bisnis Volume I Nomor 1 September 2012.

Manurung, N., \& Riani, A. L. (2017). Pengaruh Disiplin Kerja, Motivasi Kerja, Kepuasan Kerja dan Kompetensi Terhadap Komitmen Organisasi. Jurnal Manajemen Dayasaing, 18(1), 10-19.

Mangkunegara (2015). Pengaruh Motivasi, Budaya Organisasi dan Disiplin Kerja terhadap Kinerja Pegawai di Dinas Perindustrian dan Perdagangan Provinsi Jawa Tengah. Jurnal Ekonomi dan Bisnis. Vol 1. No 2.

Manzoor, S. R., Ullah, H., Hussain, M., \& Ahmad, Z. M. (2011). Effect of teamwork on employee performance. International Journal of Learning and Development, 1(1), 110-126.

Marbawi., Lumbanraja, P., Lubis, A. N., \& Siahaan, E. (2018). The Influence of Individual Characteristics and Transformational Leadership Style on Job Satisfaction and Employee Performance at Bank Aceh Sharia. In 1st Economics and Business International Conference 2017 (EBIC 2017). Atlantis Press.

Marsoit, Pingkan., Greis Sendow \& Farlane Rumokoy. (2017). Pengaruh Pelatihan, Disiplin Kerja dan Komitmen Organisasi Terhadap Kinerja Karyawan PT. Asuransi Jasa Indonesia. Jurnal EMBA. Vol 5. No 3.

Mas'ud, F. (2002.) Survai Diagnosis Organisasional Konsep dan Aplikasi, BP-UNDIP, Semarang 
Mubarak, A., \& Darmanto, S. (2015). Pengaruh Gaya Kepemimpinan Transformasional Dan Budaya Organisasi Terhadap Kinerja Pegawai Dengan Komitmen Organisasi Sebagai Variabel Intervening (Studi pada PNS di Kecamatan Watukumpul Kabupaten Pemalang). MAKSIMUM, 5(1).

Muis, M. R., Jufrizen, J., \& Fahmi, M. (2018). Pengaruh Budaya Organisasi Dan Komitmen Organisasi Terhadap Kinerja Karyawan. Jesya (Jurnal Ekonomi \& Ekonomi Syariah), 1(1), 9-25.

Murtiningsih. (2017). Pengaruh Gaya Kepemimpinan Transformasional pada Kinerja Perawat Rumah Sakit Islam Siti Aisyah Madiun. Jurnal Ekonomi \& Bisnis. Vol 2. No 3.

Mowday, R. T., Steers, R. M., \& Porter, L. W. (1979). The measurement of organizational commitment. Journal of vocational behavior, 14(2), 224-247.

Nazir, O., \& Islam, J. U. (2017). Enhancing organizational commitment and employee performance through employee engagement: An empirical check. South Asian Journal of Business Studies, 6(1), 98-114.

Nguni, S., Sleegers, P., \& Denessen, E. (2006). Transformational and transactional leadership effects on teachers' job satisfaction, organizational commitment, and organizational citizenship behavior in primary schools: The Tanzanian case. School effectiveness and school improvement, 17(2), 145-177. Nitisemito, Alex S. (2010). Manajemen Personalia. Cetakan ke 11. Edisi Keempat, Ghalia Indonesia, Jakarta.

Ningsih, D. S., \& Nofrianto, A. (2014). Pengaruh Kepemimpinan dan Komitmen Kerja terhadap Kinerja Pegawai Satuan Polisi Pamong Praja Propinsi Riau. Jurnal Online Mahasiswa Fakultas Ekonomi Universitas Riau, 1(1).

Novita, Bambang Swasto Sunuharjo \& Ika Ruhana. (2016). Pengaruh Kepuasan Kerja dan Komitmen Organisasional Terhadap Kinerja Karyawan (Studi pada PT. Telekomunikasi Indonesia, Tbk Witel Jatim Selatan, Malang). Jurnal Administrasi Bisnis . Vol 34. No 1.

Nuraini et al. (2013) Pengaruh Gaya Kepemimpinan, Motivasi kerja dan Disiplin Kerja Terhadap Kinerja Karyawan STIKES SURYA GLOBAL Yogyakarta. Jurnal Ekonomi dan Bisnis, Vol 2. No 2.

Nurdin, S., \& Rohendi, A. (2016). Gaya Kepemimpinan Transformasional, Budaya Organisasi, dan Kinerja Karyawan dengan Mediasi Komitmen Organisasi. Jurnal Ecodemica: Jurnal Ekonomi, Manajemen, dan Bisnis, 4(1), 86-100.

Nursaifullah. (2017). Pengaruh Kualitas Sumber Daya Manusia Terhadap Kinerja Pengurus Gabungan Kelompok Tani di Kabupaten Sinjai. Jurnal Ilmiah Administrasita. Vol 2. No 2.

Oktafiani, D., \& Wardhana, A. (2018). Pengaruh Disiplin Kerja Terhadap Kinerja Polri pada Kantor Polres Cilegon. E-Proceedings of Management, 5(1).

Piccolo, R. F., \& Colquitt, J. A. (2006). Transformational leadership and job behaviors: The mediating role of core job characteristics. Academy of Management journal, 49(2), 327-340.

Poltak, L. (2012). Kinerja Pegawai Teori Pengukuran dan Implikasi. Yogyakarta: Graha Ilmu.

Purnawati, N. K. E., Suparta, G., \& Yasa, P. N. S. (2017). Pengaruh Kepemimpinan Transformasional dan Pelatihan Terhadap Komitmen Organisasi dan Kinerja Pegawai Pada Dinas Perhubungan Kota Denpasar. Jurnal Ekonomi \& Bisnis JAGADITHA, 4(2), 36-54.

Rahmawan Budi., \& Jullimursyida Mariyudi (2016). Pengaruh Disiplin Kerja, Lingkungan Kerja dan Self Management Practices Terhadap Kinerja Pegawai Pada Kantor Bank Indonesia (KBI) Medan dengan Komitmen Organisasi Sebagai Variabel Mediasi. Jurnal Manajemen Indonesia (J-MIND), 1(2).

Republik Indonesia. UU No. 2 Tahun 2002 tentang Kepolisian Negara Republik Indonesia.

Rivai, V., \& Sagala, D. E. (2013). Manajemen Sumber Daya Manusia untuk Perusahaan, Jakarta: Rajawali Pers. 
Robbins, S.P., \& Judge, T.A. (2011). Organizational Behavior, Fourteenth Edition, Global edition: Pearson.

Rukhyati, R. (2018). Pengaruh Motivasi dan Disiplin Kerja Terhadap Kinerja Karyawan di Puskesmas Talise. Jurnal Sinar Manajemen, 5(2), 98-104.

Sanusi, A. (2012). Pengaruh Motivasi Kerja dan Iklim Komunikasi Organisasi terhadap Komitmen Keorganisasian Pegawai Arsip Nasional Republik Indonesia. Universitas Indonesia.

Sefriady, D. F., \& Iskandar, D. A. (2018). Pengaruh Pelatihan dan Disiplin Kerja Terhadap Kinerja Pegawai di Biro Organisasi dan Kepegawaian Sekretariat Jenderal Kementerian Perdagangan. REKAMAN (Jurnal Riset Ekonomi Bidang Akuntansi dan Manajemen), 2(1), 57-68.

Semito, Niti Alex. (2008). Manajemen Personalia. Ghalia Indonesia, Jakarta.

Setyowati. (2015). Pengaruh Kepemimpinan Transformasional dan Pelatihan terhadap Komitmen Personil pada Sat BRIMOB Polda Jawa Barat. Jurnal EMBA. 1(2).

Sholeh, M. (2017) Pengaruh Kepemimpinan Transformasional Terhadap Kepuasan Kerja Anggota yang Dimoderasi Oleh Subtitusi Kepemimpinan Pada Detasemen A Pelopor Satbrimobda di Yogyakarta. Jurnal Bisnis Manajemen. Vol 2. No 3.

Sobel, M. E. (1982). Asymptotic Confidence Intervals for Indirect Effects in Structural Equation Models. Sociological methodology, 13, 290-312.

Sonia, J. (2010). Organizational commitment and job satisfaction: a study of employees in the information technology industry in Bangalore, India (Doctoral dissertation, Christ University).

Sopiah. (2008). Perilaku Organisasional. Yogyakarta: Andi Offset.

Siswatiningsih, I., Raharjo, K., \& Prasetya, A. (2018). Pengaruh Kepemimpinan Transformasional dan Transaksional terhadap Budaya Organisasi, Motivasi Kerja, Komitmen Oganisasional dan Kinerja Karyawan. Jurnal Bisnis dan Manajemen, 5(2).

Siagian, Sondang (2007). Manajemen Sumber Daya Manusia, PT. Bumi, Jakarta.

Sinambela, L. P. (2012). Kinerja Pegawai Teori Pengukuran dan Implikasi. Yogyakarta: Graha Ilmu.

Sudarmanto. (2014). Kinerja dan Pengembangan Kompetisi SDM. Yogyakarta: Pustaka Pelajar.

Sugiyono. (2016). Metode Penelitian Bisnis. Alfa Beta, Bandung.

Sunyoto Danang dan Burhanudin. (2011). Perilaku Organisasi, Cetakan 1, CAPS, Yogyakarta.

Srimulyani, I, Rochiyati M \&, Bayu Sindhu R. (2017). Pengaruh Komitmen Organisasional terhadap Kinerja Karyawan dengan Organizational Citizenship Behavior (OCB) sebagai Variabel Moderating. The 6 University Research Colloquium 2017

Sutrisno. (2011). Manajemen Sumber Daya Manuasia. Kencana, Jakarta.

Starkie, D. (2009). The airport industry in a competitive environment: A United Kingdom perspective.

Steers, R. M., \& Porter, L. W. (1983). Motivation and work behavior. Edisi 3. United States: McGraw-Hill Book Company.

Thoha, Miftah, (2003). Kepemimpinan dalam Manajemen, cetakan kesembilan, Jakarta: PT Raja Grafindo Persada.

Thomsen, M., Karsten, S., \& Oort, F. J. (2016). Distance in schools: the influence of psychological and structural distance from management on teachers' trust in management, organisational commitment, and organisational citizenship behaviour. School Effectiveness and School Improvement, 27(4), 594-612.

Tolis, Ega D, Bakri H \& Wiri Wirastuti. (2017). Pengaruh Kepuasan Kerja dan Komitmen Organisasi terhadap Kinerja Pegawai pada Kantor Kecamatan Parigi Kota. Jurnal Ilmu Manajemen Universitas Tadulako. Vol 3. No 1. 
Viswesvaran, C., \& Ones, D. S. (2000). Perspectives on models of job performance. International Journal of Selection and Assessment, 8(4), 216-226.

Wibisino, T. (2019). Pengaruh Stres Kerja dan Komitmen Organisasional Terhadap Kinerja Pegawai Pada Sekretariat Daerah Kabupaten Tasikmalaya. Jurnal Ekonomi Manajemen, 4(2), 70-81.

Wibowo. (2007), Manajemen Kinerja. Edisi 3. Raja Grafindo Persada, Jakarta.

Yamin, Martins \& Maisah. (2010). Standarisasi Kinerja Guru. Persada Press, Jakarta.

Yudhaningsih, R. (2011). Peningkatan efektivitas kerja melalui komitmen, perubahan dan budaya organisasi. Jurnal Pengembangan Humaniora, 11(1), 40-50.

Yukl, G. (2010). Kepemimpinan dalam Organisasi, Edisi kelima. PT. Indeks, Jakarta. 